\title{
Transversal modes of being a missional church in the digital context of COVID-19
}

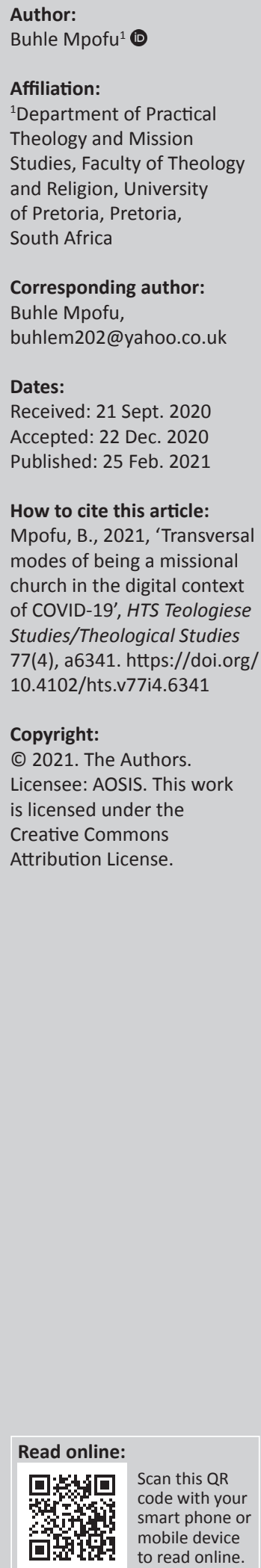

The disruptions of coronavirus disease 2019 (COVID-19) in the year 2020 reshaped all aspects of life, including religious practices and rituals. As more religious activities shifted to digital space during the lockdown periods, there was a growing need to examine the link between religion and digital media. Using the model of the Uniting Presbyterian Church in Southern Africa (UPCSA), this article draws on the notion of transversal rationality and concepts of rationality, cognitive, evaluative and pragmatic to posit that COVID-19 has configured traditional missional and liturgical spaces in ways that locate the agency of the marginalised at the centre. The article highlights how COVID-19 configured Christian mission as it disrupted power dynamics through religious digital spaces, which emerged as a new way of reimaging a missional church. These new digital spaces mediate between interaction and 'telepresence', embodied in the representations of the sacred available through online religious systems in practices where users are no longer ordinary believers - but religious participants who have power and freedom to choose. Although this is not a new phenomenon, the article concludes that such spaces created by COVID-19 shifts in power dynamics present opportunities for ordinary members to reinvent new meanings on what it means to be present or absent, to name, narrate and reinterpret the divine and forge new meanings towards participating in the mission of God.

Contribution: Although this is not a new phenomenon, this article represents a systematic and practical reflection within a paradigm in which the intersection of philosophy, religious studies, social sciences, humanities and natural sciences generate an interdisciplinary, multidisciplinary and transdisciplinary contested discourse.

Keywords: transversal rationality; digital media; missional paradigm shifts; Uniting Presbyterian Church in South Africa; COVID-19.

\section{Introduction}

Our goal should rather be to open up the boundaries between practical theology, human, social and even natural sciences. In doing so, we can enrich and broaden our sensitivity towards the human condition and human society as well as the religious community (Muller 2013:12).

In the given assertion, Muller (2013) underscored the significance of expanding practical theology through inter-, intra- and transdisciplinary studies within the field of social and natural sciences. My previous research on the interface of religion and migration laid a foundation to interrogate boundaries between practical theology and human conditions as I explored the lived religious experiences of people on the move (Mpofu 2016) through interdisciplinary lenses.

Given the complexity of challenges presented by coronavirus disease 2019 (COVID-19), it is critical that mission should draw from the fluid nature of practical theology and engage other scientific disciplines in a way that will strengthen interdisciplinary cooperation between theology and social sciences. In a similar approach to address challenges related to the human condition, Meylahn (2020) explored the question of being human in the time of COVID-19 and concluded by posing a question: What would or could be a specifically Christian calling or response in a time of COVID-19? In doing so, he underscored the need for transformation as he pointed us to 'Euangelion [good news] to proclaim in these times, as it gives one the freedom to imagine a completely new world, and therein lies the hope of the faithful' (Meylahn 2020:5).

The COVID-19 global pandemic left a trail of socio-economic destruction through disruptions to all aspects of life, including religious and missional activities as some of the religious communities halted activities during the lockdown periods. It is important to highlight that there were religious 
activities that continued during the lockdown periods, and these relied on different and often digital and social platforms. Given that during the lockdown periods, Christians and other religious communities could not congregate for traditional religious activities, this impacted on religious lives and practices prompting new ecclesiastical and missional practices that have transformed the traditional understanding of what it means to be called 'church'. Religion should be primarily concerned with understanding reality (Beyers 2010:1), and the changes necessitated by the threat of coronavirus will require a missional shift to address the limits of traditional practices and pay attention to emerging challenges (Mpofu 2020:3).

As a result of grappling with the reality of rapid change in the face of the global corona virus pandemic, the Uniting Presbyterian Church in Southern Africa (UPCSA) also suspended most of its face-to-face activities and some congregations later shifted to online virtual meetings and worship services. These disruptions also impacted on psychosocial support networks and resulted in extreme distress, given that human beings generally need one another to strengthen their coping and surviving mechanisms. Religious organisations especially the church, in times of crises, offer opportunities for interpersonal relations to enhance coping by individuals and groups through pastoral and missional activities, which respond to human challenges. The mission of the Church was negatively disrupted by COVID-19, but, considered positively, these disruptions pushed the church to reconsider what it means to participate in the mission of God in new ways. Wright (2010) defines mission as:

[F]undamentally, our mission (if it is biblically informed and validated) means our committed participation as God's people, at God's invitation and command, in God's own mission within the history of God's world for the redemption of God's creation. (pp. 22-23)

Whilst presenting the church with new challenges, COVID-19 also presented new opportunities through digital platforms as Pillay (2020:2) observed:
The electronic platforms also open new doors to Christian worshippers from different cultures and backgrounds worldwide. Worship of the triune God will always be contextual. But drawing on the rich tapestry that is the body of Christ around the globe, vibrant worship also transcends, utilises and challenges the expectations, resources and preferences of any one 'culture' to receive and respond to the good news of the Saviour (Brink and Detterman, 2013: 35). COVID-19 has strengthened the possibilities of spreading the Gospel on a broader scale and reaching the un-churched, people of other faiths and people with no faith as we grapple for answers in the current struggles in the world and tune in to electronic platforms for encouragement and hope. (p. 2)

When the UPCSA suspended physical religious activities, some congregations shifted to online virtual worship services (Langerman 2020). Although these services are limited to those with access to electronic gadgets and the Internet, this shift strengthened networks and amplified participation and empowered ordinary members. Epidemiologically, there is evidence that extensive social distancing and wearing of masks combined with general hygiene are effective ways of reducing the spread of the coronavirus. As a result, it was critical to adhere to lockdown regulations as these were meant to enhance social distancing and limit the spread of the coronavirus. However, some of these measures were difficult to implement and sustain, given that citizens are accustomed to personal freedoms and those opting to gather in smaller numbers had to comply with strict regulations. This meant that most congregations suspended religious gatherings during the period of the lockdown, but there were new forms of digital religious rituals and gatherings, which emerged as new ways of 'participating in the mission of God' (Wright 2010:24) as I will demonstrate in the sections that follow.

In recent years, mission has been undergoing rapid transformation in line with a realisation that it is critical for theology to engage contextual issues and take the situation of the marginalised seriously. For example, Niemandt (2019) observes that:

The wide acceptance and maturation of the theology of missio Dei is the most important development in the theology of mission in recent times. It introduced a radically new understanding of mission and theology, and flowing from that a re-appropriation of ecclesiology. Mission studies are also characterised by a new appreciation of mission from the margins: liberation theology and the associated discourses on decoloniality, deep engagement in contextuality and the explosion of missional ecclesiology (missional church). (p. 1)

Mission has to constantly adapt to the changing context, and in ensuring continued pastoral work in the wake of COVID-19, most churches conducted Sunday services and meetings through digital spaces. In an email circulated to church members on the 18th of September 2020, the UPCSA Mission and Discipleship (M\&D) Committee, invited members to an online 'Inspire Conference' to be held from the 13th to the 15th of October, citing the inability to have a 'physical conference' because of COVID-19 restrictions (Mpetsheni 2020a). According to this circular, the conference aimed to cover the following topics amongst others; Missional: Six Postures or ways of being that lead to growth; Pastoral: Ministry to Kids and Teens in these COVID times; Counselling during COVID; Theological: Sacraments online - discussion; When we see our neighbours as Virus Carriers; Community in an age of social distancing; Practical: Some ideas and Innovations in Lockdown; What have we learned from lockdown? Technical: What technologies are available? And Reflective: Some Important Shifts in COVID-19. The message concluded with the following words at the bottom; 'COVID-19: Flatten the Curve! Wash your Hands. Stay Calm. Be part of the Solution'. God is our refuge and strength, an everpresent help in trouble (Psalm 46:1)' (Mpetsheni 2020b).

It is not only worship services that were affected, but committees were also forced by the COVID-19 circumstances to explore new ways of conducting business and being a missional church and to continue with pastoral ministry without exposing members 
to infections through face-to-face meetings. In the light of the 'six postures or ways of being that lead to growth' as proposed by the UPCSA M\&D, what are the missional implications of these disruptions and a shift to digital space?

With the emergence of virtual religious communities, it is essential to remember that religion always involved techniques and technologies that we consider as 'media'. As Cline (2019:1) has observed, every medium necessarily participates in the realm of the transcendent, if nothing by its failure to be fully subject to the instrumental intentions of its users. It is also worth noting that, in at least one etymological account, the words 'religion' and 'communication' both refer to the work of binding together, and it is in this sense, perhaps, that religion constitutes the imaginary and figural archive for all techniques and technologies that render the world available to human will (Cline 2019:1).

As the world is undergoing rapid socio-economic transformation, there is a need for the church to be 'more flexible' (Pillay 2020), and as Jerry Pillay further observed:

[C]hurches over the centuries have preferred to talk about reformation and change to adjust to the times ... often [in] descriptive of processes and periods of slow developments ... [and] the COVID-19 pandemic has shifted churches into a somewhat revolutionary way of thinking and being church today. (p. 1)

According to Khondker (2014:6), social transformation implies a fundamental change in society, which can be contrasted with social change viewed as gradual or incremental changes over a period of time.

\section{Conceptual framework}

Drawing on the concept of 'social transformation' highlighted above, this article considers the interface between religion and technology in the shifting practices of the UPCSA mission activities and approaches human knowledge and rational judgements as constructs, which should always be understood as contextual attempts to refer to some reality and describe it. Uniting Presbyterian Church in Southern Africa Committees are tasked with the responsibility of guiding the church and in that regard, we draw from scientific theories to develop contextually informed programmes and responses to human situation. However, these responses cannot be considered a direct representation of reality because their validity or effectiveness depends on the ability to have predictive success and repeated accuracy. In reformed theology, we draw from rational judgements even in our religious endeavours. Van Huyssteen (1997:144) has rightly observed that rational judgement is an epistemic skill, and just like a physical skill it needs to be developed and internalised as it is not infallible and mistakes can be made.

In examining the missional paradigm shifts within the UPCSA, this article engages the notion of transversal rationality and concepts of rationality developed by Veldsman (2004) who identified the three resources of rationality, namely cognitive (finding good reasons for hanging on to certain beliefs), evaluative (finding good reasons for making certain moral choices) and pragmatic (finding good reasons for acting in certain ways) context. Although the former (i.e., the cognitive) is more dominant than the rest, the latter two are regarded as of the same importance (Veldsman 2004:282). Rhetoric is used to show that beliefs and actions are reasonable and Van Huyssteen (1997:133) has convincingly argued that rhetoric combines the cognitive, evaluative and pragmatic aspects of rationality, thereby making intersubjective conversations possible.

The Collins English Dictionary defines transversality as a notion that describes how spaces can intersect; it can be seen as the opposite of tangency. Driven by a deep desire to develop a framework, which facilitates interdisciplinary engagement between theology and other disciplines within social and natural sciences, Van Huyssteen (2006) observes that both theology and science are embedded in practices and traditions where interpreted experiences shape epistemic values. Therefore, interdisciplinary dialogue is possible because the same resources of rationality - and its three dimensions identified here (the cognitive, evaluative and pragmatic) - are shared across disciplines. This postfoundational approach offers significant possibilities for interdisciplinary research as he also noted that the post-Kuhn era has removed any sharp line of demarcation between scientific rationality and other forms of rationality 'because the same kind of interpretive procedures are at work in all our varied, and often widely divergent, reasoning strategies' (Van Huyssteen 2006:44-45).

It is important to highlight that there has been 'epistemological levelling' (Van Hyssteen 2006) by which science is no longer regarded as being superior to other disciplines, or necessarily distinct from them, given that all our knowledge, including direct experiential knowledge, is expressed in language, which already embodies theoretical presuppositions and therefore (Van Huyssteen 2007):

It is clear that on such an account there is going to be no significant epistemological difference between the interpretations of the empirical world and interpretations of human beings and their practices and institutions; all of these belong in the same way to our theoretical networks of beliefs about the world, and both are shaped by our worldviews, by social practices of language use, and by the epistemic and non-epistemic values that shape our behavior. (p. 47)

\section{Uniting Presbyterian Church in Southern Africa missional paradigm shifts in the digital age}

In a pastoral letter guiding congregations on reopening of places of worship the UPCSA (2020) encouraged congregations to consider a hybrid of services (physical attendance and virtual services) to avoid the second wave of COVID-19 attack and identified the following urgent areas of intervention inter alia:

- The need to fast-track the training and/or upskilling of ministers and leaders to have a working knowledge of 
technological devices, as they will be indispensable to ministry and administration, henceforth.

- Presbyteries, Sessions and Commissioners were encouraged to use the funds that were set for travelling to church official meetings for providing data, for people to access virtual meetings.

The interface of digital and religious space or narratives in the context of the COVID-19 pandemic, demonstrates how intersections of meanings are able to both modify the knowledge and create new meanings that arise from a combination or even a conflation of stories. Although these phenomena are not new, but different given that religion and the printing press (technology) have always been linked, I consider this to be sacred transversality as it offers possibilities for new meanings generated by intersections between the religious (sacred) and digital (technological) spaces in the emerging context of virtual worship. This reflects how the UPCSA drew from three resources of rationality: the cognitive, the evaluative and the pragmatic in ways that reflect the transversal nature of being a missional church in the digital context of COVID-19.

\section{The cognitive - Unsettling traditional beliefs and practices}

To find good reasons for acting in ways that help the UPCSA to explore new ways of being church, the offices of the Moderator and the General Secretary held virtual consultations with Presbytery Clerks and Moderators, and a letter (UPCSA 2020) was circulated to congregations in which they highlighted the following:

This message comes at a time when many congregations are contemplating to open the building for public worship, while some have started already, and others are still postponing. The decisions of all the Sessions are respected, as it is considered that they are taken after careful analyses of the situations and circumstances of each congregation. We encourage that the environmental analyses should always be the bases for the making of such decisions. In every situation, care should be given to adhere to the protocols and regulations that have been given by the respective governments and the health of the people should not be compromised. (p. 1)

The words used in this letter, 'contemplating', 'postponing', 'analyses', 'care' and 'adhere to protocols and regulations', reflect the cognitive nature of the UPCSA consultative and consensus nature of the decision-making processes. This message resonates with Veldsman's (2004) one of three resources of rationality, namely the cognitive (finding good reasons for hanging on to certain beliefs). By allowing for flexibility in the missional practices, as congregations consider whether to continue with digital and virtual religious worship or revert back to face-to-face gatherings, each congregation is encouraged to rationally consider regulations, which are in place. This will require making judgements on the impact of digital worship and whether such impact necessitates a shift to traditional practices.

Some of the positive things to consider will include the benefits of digital worship. Digital spaces of worship have created new virtual communities with a new form of presence, the 'non-presence', the 'anti-presence' that defines an emerging religious space and missional engagement, which is not characterised by physical association. This is consistent with the notion of 'de-secularization of the world' which was predicted by Berger (1999). This new approach to mission does not require the faithful to be physically present, as was the case with traditional methods of association. To be associated, therefore, has been appropriated a new meaning based on connectivity and 'participation' together with the other users, who are able to $\log$ in along with the other digitally connected users. In this regard, digital religious spaces present new forms of association where users build a sacred sense of belonging through online systems that are characterised by fluid and flexible narratives open to constant transformation. Based on its cognitive and digital prowess, this new way of being a church opens up religious imaginaries to innumerable missional activities and interpretations. It presents an endless missional and biblical hermeneutic that could generate new meanings.

\section{The evaluative - Finding good reasons to explore new missional practices}

The idea of allowing for flexibility in the missional practices, as congregations consider whether to continue with digital and virtual religious worship, also requires congregations to make judgements based on evaluating the local impact of COVID-19. For example, it has been demonstrated that COVID-19 has a deadlier impact on the elderly and people with underlying medical conditions (CDC 2020:1); therefore, a congregation with the majority of elderly members above 65 years of age will have to consider these implications in making decisions to avoid face-to-face gatherings.

By embracing this new form of 'presence in the non-presence' the faithful will be considered present and given full rites of membership and participation in the mission of God. Even in their physical absence, the faith members are still considered present and active, with the right to exercise full communion. The UPCSA Manual of Faith and Order understands membership to be:

Admission to membership of the Church is by baptism into the name of the Father and of the Son and of the Holy Spirit. Its members' faith in the Father and the Son and the Holy Spirit is sustained by the Ministry of the Word and Sacraments ... Those admitted as members of the Church by infant baptism shall, in due course, be urged to make public profession of their faith after such instruction as may be required. (UPCSA Manual of Faith and Order 2014:1.3)

Whilst the UPCSA Manual of Faith and Order encourages physical attendance to retain full membership, it does also concur that:

6.12 ... The Holy Spirit speaking through Scripture is the standard by which all tradition, councils, creeds, confessions and other pronouncements, all religious experience and human reasoning and all preaching and personal witness are to be 
tested. 6.13 The Spirit does not reveal truth that differs from that in Scripture, but opens our minds to the gospel and impresses on them its truth and what that means for us and our times.

Therefore, in testing the rationale behind decisions that church councils take in their local contexts, they are guided by what it means to proclaim the 'truth and what that means for us and our times'. Arriving at a rationale and contextual decision will require an informed evaluation that is based on both religious and scientific facts. This is where church members have a new way and space for exercising power in the digital age.

\section{The pragmatic - New spaces, new meanings}

In the traditional spaces of worship and religious practices, decisions are often made by church councils, and ordinary members have very little participation outside of their representatives. The digitally located virtual spaces of gathering, which emerged as a result of COVID-19 present a shift of power. Although traditional religious gathering followers do not often attend decision-making meetings, in the digital space, a common believer also has the 'power' to participate, name and narrate the divine. Not only that, the relationships created by digital discourse are also fluid and fragmentary, because the faithful members select and choose their discursive alterity (earthly or divine). Therefore, there is some deviation in the direction of a logic of access in which belonging and participating are not structured by geographical location, but by a fluid ambiance with no strings attached - as opposed to a physical church association where, in the case of UPCSA, we have seen a lot of tensions and divisions, which affected the mission of the church. Digital communities are established electronically, and without digital interaction these links simply fall away.

In essence, these new spaces of worship give a new meaning for participation in mission. You have to be online to participate, and there are no procedures or protocols as defined within the context of affiliating with the physical church - you only need data and login details such as meeting identity numbers and passwords, and then you participate fully. Although that does not immediately give you the right and access to address the audience, you are 'present in absence'. The pragmatic implications of these emerging forms of belonging and presence as non-presence generate the 'antipresence' and disrupt the traditional notion of membership because it is not necessary for the faithful to be physically there; all other users can be digitally present, along with the rest of the members who may be listed in a membership role. In that sense, digital users create a sacred space accessible to any online users, and this opens religious imaginaries to creative engagement and possible interpretations or reconstructions, which present opportunities for an endless missional hermeneutic with new meanings. These new meanings and digital liturgical spaces locate the agency of the marginalised at the centre of post-COVID-19 Christian mission and disrupt traditional power dynamics.
In being consistent with the three concepts of rationality identified by Veldsman (2004), the cognitive, evaluative and pragmatic, UPCSA Moderator issued a statement on the 20th of March 2020 after attending a meeting of religious leaders with the South African President and appealed for adherence and compliance with government regulations meant to curb the spread of the virus. Although he did not directly call congregations to suspend public worship, he highlighted that it is important for Church leaders to understand that in South Korea the majority of infections came from people who had attended church events and therefore restrictions on worship are intended to prevent people from contracting this virus at church, than risk going out and get infected or spread the virus. Stressing the need to value protocols and the scientific discourse on the pandemic, he appealed to those planning to have services to reconsider their plans and approached the matter in a way that leaves room for the Presbyterian Reformed Church practice for broader consultations and promotion of diversity of opinions, rather than being authoritative and prescriptive.

For the majority of churches that chose to continue worshipping online, this meant that religious rituals and sacred acts or practices of faith had to be reconstructed and developed through practices that appropriate new meanings within the systems, which are based on digital space and media. The UPCSA has a number of ministers who now post sermons on Face Book and YouTube, and these practices are a new form of hybrid liturgy generated through the digital space but located within the lived practices of church members. In this regard, it can be argued that digital spaces represent new religious communities marked by a logic of selection, in which the faithful are invited to re-construct their religious experiences through pre-modelled online rituals configured by the system and informed by database logic in which the sacred is symbolically transformed into a collection of data contents that can be instantly searched and found through search engines like Google. As other scholars have observed (e.g., see Berger 1980:12), an explicit algorithmic religiosity is emerging, in which the faithful make the system do what is already programmed from a sequence of liturgical gestures followed by the faithful and performed by the system. In such a context, evaluative and cognitive religious approaches promote rational dialogue with scientific discourse, and religious members are invited to deconstruct and reconstruct their faith and practices in ways that transform traditional missional and ecclesial landscapes.

\section{Conclusion}

It is in this creative discursive dialogue between religion and digital innovation that we find transversal religious narratives, which are liberating. Borrowing on the notion of transversal rationality and concepts of rationality, cognitive, evaluative and pragmatic, developed by Veldsman (2004), this article engaged the UPCSA's response to COVID-19 to explore intersections between religion and digital space. By exploring new meanings that arise from a combination or 
even a conflation of religious experiences, in this context, I proposed the term sacred transversality to describe the creation of new religious meanings at the intersection of emerging narratives generated by digital spaces, which mediate interaction through 'telepresence', embodied in the representations of the sacred available through online systems where users are no longer ordinary believers - but religious participants who have power and freedom to choose when and who they want to associate with.

Considering the approach taken by the UPCSA leadership, I highlighted points at which scientific narratives intersect with religion in a way that is enriching. By intersecting religion and digital media, this article notes that there is a need to explore new meanings and ways of being a missional church given that digital spaces mediate interaction through 'telepresence', embodied in the representations of the sacred available through online systems where users are no longer ordinary believers but have assumed symbolic power and freedom to name, narrate and interpret the divine by forging new meanings towards participating in the mission of God. The article concludes that digital users create a sacred space accessible to ordinary people, and this presents opportunities for an endless missional hermeneutic with new meanings and generates digital liturgical spaces, which locate the agency of the marginalised at the centre of post-COVID-19 Christian mission, and disrupts traditional power structures.

\section{Acknowledgements}

The author would like to acknowledge the statements issued by the Uniting Presbyterian Church in Southern Africa (UPCSA) during the COVID-19 period and the engagement with the various church leaders regarding the challenges posed by COVID-19 through discussions in various online platforms.

\section{Competing interests}

The author solemnly declares that he has no financial or personal relationship(s), which may have inappropriately influenced him in writing this article.

\section{Author's contribution}

I declare that I am the sole author of this research article.

\section{Ethical considerations}

Ethical approval for this study was obtained from the Research Committee, Faculty of Religion and Theology, University of Pretoria (T027/20).

\section{Funding information}

The research received no specific grant from any funding agency in the public, commercial or not-for-profit sectors.

\section{Data availability}

Data sharing is not applicable to this article as no new data were created or analysed in this article. Data collected through a questionnaire and cleared by the research committee are yet to be received and analysed.

\section{Disclaimer}

The views and opinions expressed in this article are those of the author and do not necessarily reflect the official policy or position of any affiliated agency of the author.

\section{References}

Berger, P.L., 1980, Heretical imperative: Contemporary possibilities of religious affirmation, p. 28, Doubleday, New York, NY.

Berger, P.L., 1999, 'The desecularization of the world', in P.L. Berger (ed.), The desecularization of the world: Resurgent religion and world politics, pp. 1-18, WB Eerdmans Publishing Company, Grand Rapids, MI.

Beyers, J., 2010, 'What is religion? An African understanding', HTS Teologiese Studies/ Theological Studies 66(1), a1089. https://doi.org/10.4102/hts.v66i1.1089

Brink, E.R. \& Detterman, P., 2013, Wise church: Exploring faith and worship with Christians around the world, Faith Alive, Grand Rapids, MI.

Center for Disease Control (CDC), 2020, Corona virus disease 2019 (COVID-19): People with certain medical conditions, viewed 21 September 2020, from https://www. cdc.gov/coronavirus/2019-ncov/need-extra-precautions/people-with-medicalconditions.html.

Cline, A., 2019, The relationship between technology and religion, viewed 19 September 2020, from https://www.learnreligions.com/technology-as-religion4038599.

Khondker, H.H. 2014, Social transformation, development and globalization, viewed 09 December 2020, from https://www.researchgate.net/publication/323952006 Social_transformation_development_and_globalization

Langerman, P., 2020, 'Uniting Presbyterian Church in Southern Africa', Moderator's letter, received on email dated Friday 20 March 2020.

Meylahn, J-A., 2020, 'Being human in the time of COVID-19', HTS Teologiese Studies/ Theological Studies 76(1), a6029. https://doi.org/10.4102/hts.v76i1.6029

Mpetsheni, L., 2020a, 'Uniting Presbyterian Church in Southern Africa (UPCSA)' Mission and discipleship, received on email dated 18 September 2020

Mpetsheni, L., 2020b, 'Uniting Presbyterian Church in Southern Africa (UPCSA)', Message to all in the UPCSA on opening for public worship in COVID-19 times, Circular to all UPCSA congregations, received on email dated 12 September 2020.

Mpofu, B., 2016, 'When the people move, the church moves: A critical exploration of the interface between migration and theology through a missiological study of selected congregations within the Uniting Presbyterian Church of Southern Africa in Johannesburg', Unpublished PhD thesis, University of KwaZulu Natal School of Classics Religion and Philosophy.

Mpofu, B., 2020, "It is now in your hands": South Africa's dilemma for religion and governance in the changing COVID-19 context', HTS Teologiese Studies/ Theological Studies 76(1), a6183. https://doi.org/10.4102/hts.v76i1.6183

Müller, J.C., 2013, 'Practical theology as part of the landscape of social sciences and humanities - A transversal perspective', HTS Teologiese Studies/Theological Studies 69(2), a1299. https://doi.org/10.4102/hts.v69i2.1299

Niemandt, N., 2019, 'A missional hermeneutic for the transformation of theological education in Africa', HTS Teologiese Studies/Theological Studies 75(4), a5406. https://doi.org/10.4102/hts.v75i4.5406

Pillay, J., 2020, 'COVID-19 shows the need to make church more flexible', Transformation 37(4), 266-275. https://doi.org/10.1177/0265378820963156

UPCSA, 2014, 'Uniting Presbyterian Church in Southern Africa (UPCSA)', Manual of faith and order, UPCSA Print, Johannesburg.

Van Huyssteen, J.W., 1997, Essays in postfoundationalist theology, William B. Eerdmans, Grand Rapids, MI.

Van Huyssteen, J.W., 2006, 'When our bodies do the thinking: Theology and science converge', American Journal of Theology \& Philosophy 27(2), 127-153.

Van Huyssteen, J.W., 2007, 'Response to critics', American Journal of Theology \& Philosophy 28(3), 409-432.

Veldsman, D., 2004, 'Re-visiting the implications of contemporary epistemological models for the understanding of religious experience: An overview', Religion and Theology 11(3\&4), 278-297.

Wright, C.J.H., 2010, The mission of God's people, Zondervan, Grand Rapids, MI. 